УДК 37.091.12:005.963.2(438)

DOI:

Катерина Осадча, кандидат педагогічних наук, дочент кафедри інформатики і кібернетики

Мелітопольського державного педагогічного університету імені Богдана Хмельницького

\title{
ДОСВІД ТЬЮТОРСТВА ТА ПІДГОТОВКИ ТЬЮТОРІВ У ПОЛЬЩІ
}

Досліджено становлення тьюторства у Польщі, щуо розвивалося під впливом монастирських шкіл та університетів, у XVIII - XIX cm. практично не застосовувалось як форма індивідуального навчання через відносно високі витрати, а нині постає актуальним у зв'язку із процесами модернізації польської освіти. Виділено тематичні напрями польських наукових робіт з тьюторства. Подано варіанти визначення поняття “тьютор” $і$ “тьюторство” у польській педагогічній думщі. 3 'ясовано, щзо у Польщі програми підготовки тьюторів протягом певного часу проводились в академічних та неурядових організаціях 6 основному шляхом проведення тренінгів. Навчальні заклади Польщі пропонують підготовку тьюторів через аспірантуру. Визначено напрями використання досвіду Польщі, щчо мають адаптаційний потенціал у підготовиі тьюторів в Україні.

Ключові слова: тьюторство; підготовка тьюторів; досвід Польщі; тьюторскі програми.

Jim. 9.

Kateryna Osadcha, Ph.D.(Pedagogy), Associate Professor of the Computer Science and Cybernetics Department, Melitopol Bohdan Khmelnytskiy State Pedagogical University

\section{EXPERIENCE OF TUTORING AND TRAINING TUTORS IN POLAND}

The formation of tutoring in Poland, which developed under the influence of monastic schools and universities, was studied in the 18th-19th centuries. Practically it was not used as a form of individual training due to relatively high costs. Today it becomes relevant in connection with the modernization of Polish education. Thematic directions of Polish scientific works on the tutoring topic are highlighted: publications in which the authors concentrate on describing the role of tutor-teacher, teacher, educator as a private tutor. There are scientific works in which tutoring is an educational strategy of teaching the individual subjects, vocational training and resocialization, also publications about peer education, in which children play the role of tutor and pupil. The options of defining the concepts "tutor" and "tutoring" in Polish pedagogical thought are presented. It has been established that in Poland training programs for tutors of a certain time were conducted in academic and public organizations. At the present stage, the training is carried out mainly through training and training courses with obtaining certificates. In Poland, there is accreditation of teachers both tutors and educational institutions, such as those that apply tutoring practices. Polish educational institutions offer the preparation of tutors through postgraduate study, and its graduates receive a certificate of completion after the final examination in accordance with the model Ministry of Science and Higher Education. The directions of using the Poland experience, which have the adaptive potential in the preparation of tutors in Ukraine, are defined: distribution and rationing of the most effective and promising types for tutoring (peer tutoring, tutoring at work, tutoring in inclusive education); introduction of the tutors training, the certification of tutorial practices, informal and informational tutoring training into the practice of state and non-state organizations; the use of tutoring at all education levels and in inclusive education.

Keywords: tutoring; preparation of tutors; the experience of Poland; Tutorial programs.

П остановка проблеми. В умовах реформування вітчизняної освіти та пошуку шляхів їі удосконалення для підготовки підростаючого покоління до життя в інформаційному суспільстві зростає увага до індивідуалізації. Однією $з$ ефективних практик індивідуалізацї визнано тьюторство (А.М. Бойко, Т.М. Ковальова, Л.Г. Настенко). Проте проблема професійної підготовки педагогів до тьюторської діяльності не отримала належного висвітлення у вітчизняній теорії і практиці. У зв’язку із цим доцільним напрямом дослідження вважаємо здійснення аналізу досвіду провідних країн світу, зокрема Польщі, щодо тьюторських практик та підготовки тьюторів.

Аналіз основних досліджень і публікацій. Дослідженням тьюторства у зарубіжних країнах займалися В.Є. Абрамович, К.О. Алєксандрова, К.О. Андрєєва, Ж. Борде, О.А. Власова, В. Мирошниченко, С.Г. Молчанов, Т. Пахомова Р.В. Шаран та ін. Тьюторські технології у роботі зі школярами висвытлено у працях Т.М. Гущіної, Ю.А. Лях, К.П. Осадчої [6], О.А. Чекунової. Історичні аспекти тьюторства висвітлював A. Фіялковський (A.Fijaikowski), сутність тьюторство розглянуто А. Сарнат-Чіастко 
(A. Sarnat-Ciastko), компетентності тьютора подано М. Косно (M. Kosno), тьюторство, що базується на індивідуалізованому підході до студента, досліджували А.I. Бжезинська (A.I. Brzezinska) та Л. Ричульська (L. Rycielska). Окремі аспекти тьюторської діяльності у школі висвітлювали П. Чекерда (P. Czekierda), M. Буджинський (M. Budzyński), Я. Трачинський (J. Traczyński), 3. Залевський (Z. Zalewski) та інші польські науковці. Саме висвітлення вищезазначеної проблеми у працях цих науковців стало підгрунтям нашого дослідження польського досвіду тьюторства та підготовки тьюторів.

Мета дослідження - на основі аналізу наукових публікацій та мережних джерел вивчити досвід тьюторства та підготовки тьюторів у Польщі та виділити у ньому потенційно адаптаційні шляхи професійної підготовки тьюторів в Україні. Для досягнення мети були поставлені такі завдання: проаналізувати витоки тьюторство у польській освіті, 3 метою дослідження феномену тьюторства у Польщі здійснити пошук у польській бібліографічній базі даних наукових статей та проаналізувати його результати, вивчити досвід підготовки до тьюторської діяльності у Польщі, висвітлити напрями використання польського досвіду підготовки тьюторів.

Виклад основного матеріалу дослідження. Тьюторство у Польщі розвивалося, як пише А. Фіялковський [2], під впливом монастирських шкіл та університетів Франції, Німеччині, Італії та Англії. Відповідно до його дослідження поняття “тьютор" як індивідуальний учитель або наставник, досить часто можна знайти в історичних джерелах у Польщі до епохи Просвітництва. Згодом у XVIII - XIX ст. відмовилися від такої форми індивідуального навчання через відносно високі витрати. Нині у Польщі постає питання, чи така форма індивідуальної підготовки та виховання повинна бути запроваджена у польських університетах.

Тьюторство у польській освіті, як зазначає А. Сарнат-Чіастко [9], впровадив професор 3. Пелчинський (Z. Pełczyński). Заснована ним школа для молодих суспільних і політичних лідерів, яка тепер має назву “Школа Лідерів”, 3 1994 року виховує лідерів на основі метода тьюторінгу. Через рік запропонований ним метод навчання був використаний у Gofron Basics of Education і художній середній школі "ALA" (Autorskie Licea Artystyczne i Akademickie) y Вроцлаві. У 2009 році до розробки методу долучився багаторічний практик тьюторінгу П. Чекерда. Разом із співробітниками Collegium
Wratislaviense він вирішив надати тьюторінгу чіткі межі й стандарти й пристосувати його до шкільних і академічних реалій Польщі.

3 метою дослідження феномену тьюторства у Польщі нами було здійснено пошук за словом “тьютор" у польській бібліографічній базі даних наукових статей (http://mak.bn.org.pl) та каталозі національної бібліотеки (http://katalogi.bn.org.pl). На основі аналізу контексту, в якому в заголовках 69 текстів використовується слово “тьютор”, що $\epsilon$ словотворчою основою слова “тьюторство”, ми виділити три тематичні напрями, пов’язані із застосуванням тьюторства у польській освіті: до першої групи ми віднесли публікації, в яких автори зосереджені на ролі тьютора-учителя, викладача, вихователя як приватного тьютора, посилаючись на основне значення цього терміну, окресленого у праці А. Сарнат-Чіастко, визначаючи тьюторство як альтернативу формальній освіті. Друга тематична група позиціонує тьюторство як освітню стратегію, що застосовується на різних рівнях освіти (від початкової школи до університетської) з урахуванням різного змісту навчання (очне і дистанційне) та різних одержувачів (учні, інвалідів, іноземні студенти) 3 метою навчання окремим предметам, професійного навчання та ресоціалізації. Третя тематична група складається 3 праць про навчання однолітків, в яких роль тьютора та учня виконують діти. Важливо те, що деякі автори (М. Косно [4]) наголошують на перевазі такого навчання зважаючи на переваги когнітивного навчання одного і того ж віку.

Крім того, є книги польських авторів, присвячені тьюторству. Наприклад, колективна робота “Тьюторство у школі - між теорією та практикою змін у навчанні” (Tutoring w szkole między teorią a praktyką zmiany edukacyjnej) [1], пропонує опис досвіду та знань з впровадження тьюторських практик у школі. Автори позиціонують тьюторство як один з методів індивідуального навчання, який базується на безпосередній зустрічі тьютора $з$ учнем чи студентом. Тьютор - це людина, яка володіє знаннями, досвідом та відповідною освітою, а також здатна працювати в умовах міжособистісної взаємодії. Тьюторство розглядається як довгостроковий (в тому числі, принаймні один семестру) процес співпраці, орієнтований на інтегральний - у тому числі знань, навичок і вмінь - розвиток підопічного. Суть тьюторства полягає в індивідуальних зустрічах, де атмосфера діалогу, взаємної поваги і уваги тьютора з підопічним дозволяє їм зануритися в конкретні галузі знань, розвинути здібності 
самостійно здобувати і розвивати мистецтво максимального використання своїх талантів. Автори переконані, що такий метод, який адаптується до учня деякою мірою, дає можливість для розвитку як початківців, так і середніх та талановитих студентів.

Польський дослідник Я. Трачинський (J. Traczyński) вважає, що тьюторство являє собою процес, що складається з п'яти різних етапів: пізнання підопічного (побудова хороших відносин, діагностика), визначення цілей розвитку, планування розвитку, реалізація планів (мотивація, контроль) і оцінювання результатів (досягнення). Метою співпраці тьюторської є особистий та науковий розвиток людини, i його сутність полягає в спільному залученні до діяльності обох сторін. Завдання тьютора - не вирішувати проблеми підопічного, а у спільній роботі досягти успіху двох сторін. На думку Я.Трачинського, тьютор “працює” в першу чергу на майбутне підопічного: що ви можете, що ми можемо зробити? Він зосереджується не на проблемах, а на можливостях їх вирішення, знає, коли звертатися за допомогою до інших фахівців (психолог, консультант, лікар-психіатр, юрист) i, в разі необхідності, використовує їх допомогу. Тьютор забезпечує цінності, тому він може стати керівником на дорогах, що ведуть до Істини, Добра та Краси. Добро підопічного є найвищим значенням для тьютора [1, $34-35]$.

Таким чином, розуміння тьюторства, запроваджене у польську освіту 3. Пелчинським, описане у колективній роботі “Тьюторство у школі - між теорією та практикою змін у навчанні”, отримало розвиток у діяльності Асоціації відкритої освіти (Towarzystwo Edukacji Otwartej (TEO), Коледжу тьюторів (Kolegium Tutoryw) та Авторського художньо-академічного ліцею. Джерелом моделі став англосакський підхід до тьюторства, вона є оригінальною, авторською, випробуваною на практиці моделлю тьюторства, що грунтується на взаємовідносинах "майстеручень”, позитивній психології та етиці чеснот, приділяючи особливу увагу розвитку характеру учня. Польські педагоги вважають, що важливо прищеплювати підопічним такі цінності й якості характеру, які допоможуть їм у майбутньому бути самостійними і розвиватися, примножуючи не лише свої здобутки, а й збагачуючи суспільство.

У Польщі тьюторські програми протягом певного часу проводились в академічних та неурядових організаціях. Деякі школи, особливо недержавні, також використовують цей метод. Протягом останніх двох років Коледж тьюторів (Kolegium Tutorów) завершив декілька тьюторських програм для вчителів середніх і середніх шкіл та спробував провести пілотне введення в навчальні заклади для громадських середніх шкіл у Вроцлаві.

Як зазначає польський дослідник Я. Трачинський $[1,35$ - 36], найчастіше вчителі готові працювати з групою учнів - класом. Деякі 3 них дуже добре працюють на індивідуальній роботі і завдяки своєму досвіду можуть взяти на себе роль тьютора без будь-якої формальної підготовки. Однак робота тьютора стає більш ефективною завдяки додатковому тренінгу та нагляду іншого досвідченого тьютораконсультанта. Для цього у Коледжі тьюторів було розроблено модель підготовки тьюторів: формування тьюторської компетентності (близько 180 г.) + робота 3 тьютором-консультант + практика в школах, схильних до постійної рефлексії (забігаючи свої власні підручники) (мінімум 1 год на місяць). Досвід Коледжу тьюторів показує, що основна підготовка тьютора триває рік; оптимально, якщо це відбудеться протягом навчального року. Через рік тьютор може працювати з іншими викладачами та бути тьютором-консультантом. Через два роки тьютор може спробувати свої сили як тьютор-тренера, який здійснює підготовку інших викладачів до роботи. Через два роки репетитор може спробувати свої сили в якості вихователя тренера, який готує інших викладачів до роботи. Завдяки конкретному видуроботи (взаємовідносини “один на один”), викладачі працюють, насамперед, на основі свого досвіду та намагаються розробити власний профіль тьюторської роботи.

У Вроцлавському колегіумі (Collegium Wratislaviense) для людей, пов'язаних з освітою у “Школі тьюторів” (Szkoła Tutorów) пропонується 64-годинна програма, що завершується отриманням сертифікату І-го рівня. Вона спрямована на навчання ефективній тьюторській діяльності на робочому місці. Слухачі школи ознайомлюються 3 такими тематичними напрямами як визнання потенціалу підопічного, відкриття та зміцнення його сильних сторін і талантів, покращення відносин між учнями та учителем; зміцнення авторитету вчителя та викладача; вирішення освітніх завдань шляхом індивідуальної роботи 3 підопічним; радість і задоволення від дидактичної роботи; попередження професійного вигоряння учителів та викладачів.

Програма навчання тьюторів передбачає ознайомлення з такими темами: “Введення в тьюторство” (“Тьюторство: теоретичні основи та прогресивні методи навчання в Польщі та у світі”, 
“Антропологія та мета навчання”, “Підготовка та проведення першого навчального тьюторіалу”), “Тьюторство і розвиток” ("Позитивна психології в тьюторингу”, “Персоналізована освіта та розвиток талантів", “Методи підтримки талантів та сильних сторін”, “Встановлення цілей та мотиваціï”, “Інструмент коучингу в навчанні”), “Наукове навчання та планування" (“Есе як інструмент для роботи 3 підопічним - від формулювання питання, через оцінку, до бесіди”, “Планування та підготовка навчальних циклів”, “Впровадження тьюторських програм та проектів”), “Розвиток тьюторства” (“Найпоширеніші проблеми в тьюторстів", “Цінності в навчанні тьюторіали”, “Тьютор як лідер”) [10].

“Школа тьюторів” надає можливості для акредитації педагогів як тьюторів та навчальних закладів, як таких, що застосовують тьюторські практики. Програм акредитації у школі існує кілька: акредитована практика тьюторства шлях після ST, акредитована практика тьюторства - шлях після РТ, програма оновлення тьюторської акредитації. Перша програма “Акредитована практика тьюторства - шлях після ST" - $є$ пропрієтаною освітньою програмою, яка $\epsilon$ наступним етапом розвитку кар'єри тьюторів. Програма відповідає потребам продовження поглиблення знань та навичок тьюторів 3 акцентом на практичну сторону методу, створюючи простір для тьюторства на польському освітньому ринку. Вона також $\epsilon$ процесом встановлення стандартів професії тьютора. Вона зосереджує увагу на практичному аспекті тьюторства та спрямована на підтримку викладачів у впровадженні незалежних навчальних проектів, підготовці їх до ролі консультування з питань тьюторингута підтримці в побудові власного бренда як тьютора на ринку освіти. Особливостями програми є те, що у процесі інтенсивної практики, кожен учасник Програми акредитації буде реалізовувати два навчальні проекти (що складаються 3 щонайменше 8 навчальних тьюториалів) 3 підопічними (учнями чи студентами). У ході програми здійснюється індивідуальний нагляд за роботою викладачів, які беруть участь у Програмі: кожен тьютор бере участь у мінімум 4 наглядових сесіях; передача нових знань та навчання нових інструментів тьюторингу; поглиблений аналіз практичних прикладів; самовдосконалення власної роботи відповідно до етичного кодексу тьютора; поглиблення рефлексії тьюторської діяльності; побудова власного бренду як тьютора на ринку освіти; аналіз ринкових можливостей професії тьютора, включаючи опис ділових можливостей учасників програми та розробку тьюторських профілів та пропозицій на загальнонаціональному порталі tutoring.edu.pl; набір готових інструментів для підтримки тьютора у роботі з підопічним.

Підготовка тьюторів за цією програмою здійснюється у процесі вивчення таких тем: “Межі тьюторства”, “Тематичне дослідження”, “Спілкування у тьюторстві”, “Прийняття рішень”, “Групові супервізії”, “Кодекс етики тьютора”, “Ідентичність тьютора", "Побудова особистого бренду тьютора”, “Інструменти для натхнення та зміни перспективи”.

Перевірка знань за програмою здійснюється шляхом оцінювання написаного тематичного дослідження 3 практики тьюторства та запису (відео чи аудіо) зустрічі тьютора 3 підопічним. Процес акредитації завершується під час Польського національного тьюторського конгресу у Варшаві, де кожній акредитованій практиці тьюторства гарантована безоплатна участь у цьому заході [8].

Інша “Акредитована практика тьюторства шлях після РТ” дозволяє доповнити другий етап навчання. У процесі підготовки тьюторів за цією програмою слухачі знайомляться 3 такими теоретичними питаннями: “Етичний кодекс тьютора" - основні етичні принципи в роботі тьютора і отримання можливості приймати рішення в разі етичних дилем, з якими стикається наставник; “Ідентичність тьютора” - глибокий самоаналіз себе як тьютора, що призводить до поглиблення власної самосвідомості; “Розробка індивідуального бренда тьютора" - визначення свого бренду як тьютора, розробка способів побудови позиції на ринку освіти, розробка пропозиції комерційного тьютора і ії просування; “Інструменти натхнення та зміни перспективи” надання додаткових ідей для проведення зустрічей ініціативних та активних. Перевірка знань за програмою здійснюється шляхом оцінювання 20-хвилинного тесту для перевірки теоретичних основ тьюторства та запису (відео чи аудіо) зустрічі тьютора $з$ підопічним. Процес акредитації також проводиться на Польському національному тьюторському конгресі [7].

Програма оновлення тьюторської акредитації запровадження для того, щоб гарантувати якість програм акредитації тьюторів, дозволяючи подовжити акредитацію після 2-х років 3 дати отримання сертифіката про акредитацію. Для оновлення акредитації потрібно документальне підтвердження тьюторської діяльності на рівні 80 балів за 2 роки. Для цього потрібно приймати участь у Національному тьюторському конгресі. 
Підготовку тьюторів здійснює також Фундація “Колегіум тьюторів” [3]. У рамках діяльності цієї фундації проводяться курси початкового рівня 3 навчання вчителів і педагогів індивідуальним методам роботи та тьюторські курси другого рівня, що надають поглиблені знання про тьюторство і підготовку до ролі тьютора як консультанта і керівника команди шкільних тьюторів. Разом з Колегією Da Vinci в Познані “Колегіум тьюторів” здійснює підготовку тьюторів через аспірантуру за кількома напрямами, а саме: консультування по кар'єрі, освіта і терапія людей з аутизмом 3 елементами сенсорної інтеграції, дитяча та дошкільна освіта, цифрова графіка і мультимедіа для учителів, методи навчання, педагогічна підготовка, навчання історії та соціальним знанням, педагогічна підготовка до викладання професійних предметів, керування освітою (лідерство, управління, розвиток) тощо. Заняття в аспірантурі проводяться увихідні дні, кожні два тижні. Умовою для проходження післядипломного навчання і отримання сертифікатує 80\% відвідуваності занять і отримання всіх кредитів і екзаменів, передбачених програмою, атакожпідсумкового (дипломного) іспиту. Випускники отримують свідоцтво про закінчення аспірантури відповідно до моделі Міністерства науки і вищої освіти.

У рамках польського проекту “Виховати мудру людину” (Wychować człowieka mądrego) [5], який здійснюється за підтримки Міністерства національної освіти (Ministerstwo Edukacji Narodowej), Товариства відкритої освіти (Towarzystwo Edukacji Otwartej) та Інституту шкільного тьюторства (Instytut Tutoringu Szkolnego), здійснюється підготовка шкільних учителів д тьюторської діяльності. Навчальний курс проходить у кожній школі, яка підключається до проекту. Заняття знайомлять учасників 3 методами тьюторської роботи заснованої на положеннях педагогіки діалогу та відповідними організаторськими та діагностичними інструментами. Важливим елементом курсу $\epsilon$ підготовка учителів до встановлення зв'язків 3 батьками, налагодження партнерської співпраці між обома сторонами. Курс ведеться практиками - командою 3 декількох десятків тренерівтьюторів, більшість 3 яких працюють 3 цим методом кожен день. Навчання складається 3 лекцій та семінарів, які знайомлять учасників 3 такими питаннями: введення в репетиторство та педагогіку діалогу; створення взаємин у шкільному середовищі, співпраця з батьками; визнання сильних сторін учня та їх використання в тьюторіалі; визначення цілей навчання та створення планів та програм їх досягнення; супровід та моніторинг виконання планів та шляхів розвитку учня; зворотній зв' язок і саморефлексія в навчанні, оцінювання роботи учня - оцінювання роботи тьютора; творчість вихователя та його учня; цінності в роботі тьютора - етика в роботі тьютора. Для отримання сертифікату щодо завершення навчального курсу потрібно 100\% відвідуваність.

Висновки. Таким чином, проаналізувавши досвід тьюторства та підготовки тьюторів у Польщі, у дослідженні виділено кілька напрямів використання польського досвіду підготовки тьюторів, що мають адаптаційний потенціал в Україні: поширення та унормування найбільш ефективних і перспективних видів тьюторства (студентське тьюторство, тьюторство на виробництві, тьюторство в інклюзивній освіті); запровадження роботи державних і недержавних організацій для підготовки тьюторів, сертифікації тьюторських практик, неформальної та інформальної тьюторської підготовки; застосування тьюторського супроводу на всіх щаблях освіти та в інклюзивній освіті.

\section{ЛIТЕРАТУРА}

1. Tutoring w szkole - między teorią a praktyką zmiany edukacyjnej / Czekierda P. i in. (red.).. - Wrocław: Towarzystwo Edukacji Otwartej. - 2009. - $115 \mathrm{~s}$.

2. Fijałkowski A. Z dziejów myśli o tutoringu - krótki zarys historii indywidualnego kształcenia i wychowania / A. Fijałkowski // Kwartalnik Pedagogiczny. - 2009. - №2. -s. 5-34.

3. Fundacja Kolegium Tutorów. [Електронний pecypc]. - Режим доступу: URL: http://tutoring.pl.

4. Kosno M. Kompetentny tutor. Znaczenie funkcji zarządzających dla przebiegu tutoringu rówieśniczego / M. Kosno // Psychologia Rozwojowa. - 2013. - 18. nr 4. s. $95-110$.

5. Осадча К.П. Специфіка організації тьюторського супроводу учнів початкової школи // Молодь і ринок. №5 (148). - 2017. - С. 63-69.

6. O projekcie. [Електронний ресурс]. - Режим доступу: URL: http://sp48gdy.webd.pl/do_wymiany/ Tutoring/index.html.

7. PROGRAM Akredytowany Praktyk Tutoringu ścieżka po PT. [Електронний ресурc]. - Режим доступу: URL: http://www.tutoring.edu.pl/program-akredytowanypraktyk-tutoringu-sciezka-po-pt,47.

8. PROGRAM Akredytowany Praktyk Tutoringu ścieżka po ST. [Електронний ресурс]. - Режим доступу: URL: http://www.tutoring.edu.pl/program-akredytowanypraktyk-tutoringu-sciezka-po-st,46.

9. Sarnat-Ciastko A. Tutor a wychowawca. Rzeczywistość nadana czy wybrana // A. Sarnat-Ciastko. - Podstawy Edukacji. -2010. - 3. - s. 76-88.

10. Szkoła Tutorów. [Електронний ресурс]. - Режим доступу: URL: http://cw.edu.pl/program/szkola-tutorow. 


\section{REFERENCES}

1. Czekierda, P. i in. (red.) (2009). Tutoring w szkolemiędzy teoria a praktyka zmiany edukacyjnej [Tutoring at school - between theory and the practice of educational change]. Wrocław: Towarzystwo Edukacji Otwartej. [in Polish].

2. Fijałkowski, A. (2009). Z dziejów myśli o tutoringukrótki zarys historii indywidualnego ksztatcenia $i$ wychowania [From the history of thinking about tutoring - a brief outline of the history of individual education and upbringing]. Kwartalnik Pedagogiczny, no. 2, pp.5-34. [in Polish].

3. Fundacja Kolegium Tutorów [The Tutor Collegium Foundation]. Available at: http://tutoring.pl. [in Polish].

4. Kosno, M. (2013). Kompetentny tutor. Znaczenie funkcji zarzadzajacych dla przebiegu tutoringu rówieśniczego [Competent tutor. The importance of management functions for the course of peer tutoring]. Psychologia Rozwojowa, 18, no. 4, pp.95-110. [in Polish]

5. Osadcha, K. (2017). Spetsyfika orhanizatsii tiutorskoho suprovodu uchniv pochatkovoi shkoly [The specific of organization of the tutors support of students of primary school]. Yoth \& market, vol. 5(148), pp. 63-69. [in Ukrainian].

6. O projekcie [About the project]. Available at: http:// sp48gdy.webd.pl/do wymiany/Tutoring/index.html. [in Polish].

7. PROGRAM Akredytowany Praktyk Tutoringu ścieżka po PT. [PROGRAM Accredited Tutoring Practice - path after PT]. Available at: http://www.tutoring.edu.pl/ program-akredytowany-praktyk-tutoringu-sciezka-popt,47. [in Polish].

8. PROGRAM Akredytowany Praktyk Tutoringu ścieżka po ST. [PROGRAM Accredited Tutoring Practice - path after ST]. Available at: http://www.tutoring.edu.pl/ program-akredytowany-praktyk-tutoringu-sciezka-post,46. [in Polish].

9. Sarnat-Ciastko, A. (2010). Tutor a wychowawca. Rzeczywistość nadana czy wybrana [Tutor and educator. The reality given or chosen]. Podstawy Edukacji, 3, pp.7688. [in Polish].

10. Szkoła Tutorów. Available at: http://cw.edu.pl/ program/szkola-tutorow. [in Polish].

Стаття надійшла до редакції 28.05.2018

УДК 7.03(477)

DOI:

Оксана Петрів, кандидат філософських наук, дочент кафедри культурології та мистецьької освіти Дрогобицького державного педагогічного університету імені Івана Франка

\section{ЕТНОКУЛЬТУРНИЙ ВИМІР УКРАЇНСЬКОЇ ХУДОЖНЬОЇ КУЛЬТУРИ ПОЧАТКУ 20 СТ.}

У статтірозглянутоособливостіукраїнськоїхудожньоїкультурипочатку $20 \mathrm{~cm}$., якарозвивалася уруслінаміонального відродження $і$ збережкення етнічної самобутності та ідентичності в умовах радянської тоталітарної держсави. Показано культурно-мистечьку ситуацию початку 20 ст., вказано на вияв активної національної свідомості української творчої еліти. Обтрунтовано, що украӥнська культура початку $20 \mathrm{~cm}$. характеризується відродженням національних ицінностей, етнічних традииій, зростаннямнаиіональної свідомості тавідображенням етнічної самобутності ухудожсній культурі.

Ключові слова: художня культура; мистеитво; етнічна культура; національне відродження; начіональна свідомість; етнічна самобутність.

Jim. 11.

Oksana Petriv, Ph.D. (Philosophy), Associate Professor of the Cultural Studies and Artistic Education Department

Drohobych Ivan Franko State Pedagogical University

\section{ETHNOCULTURAL DIMENSION OF UKRAINIANARTISTIC CULTURE AT THE BEGINNING OFTHE 20TH CENTURY}

The article considers the special features of the Ukrainian artistic culture of the early 20th century, which developed in line with the national revival and the preservation of ethnic selfhood and identity in the conditions of the Soviet totalitarian state. It shows the cultural and artistic situation at the beginning of the 20th century and indicates the expression of active national consciousness of the Ukrainian creative elite. The research substantiates that the Ukrainian culture of the early 20th century was characterized by the revival of national values, ethnic traditions, the growth of national consciousness and the reflection of ethnic identity in artistic culture. It has been revealed that the Ukrainian art of this age largely reflected the complexity, ambiguity and peculiarity of the political, national and cultural situation in Ukraine. The development of the Ukrainian art of the 1920s and 1930s went beyond purely artistic problems, hence it was closely linked to the prospect of the national and cultural development. The emergence of the outlook of artists of this age was influenced by the sources of ethnic culture (folk art, Ukrainian icon painting, ornamentation), which determined the originality and national specificity of their works. Beginning in 1933, the communist government was severely controlling the ideological situation in the country, cultural 